\title{
ANALYSIS OF PHYSICAL EDUCATION LEARNING OUTCOMES RUNNING 40 METER
}

\author{
Nur Indah Atifah Anwar', Juhanis ${ }^{2}$, M.Adam Mappaompo ${ }^{3}$, \\ Iskandar $^{4}$, Andi Saparia ${ }^{5}$ \\ Universitas Negeri Makassar ${ }^{1,2,3,4}$, Universitas Tadulako ${ }^{5}$ \\ nurindah@unm.ac.id
}

\begin{abstract}
Analysis of Physical Education Learning Outcomes 40 M Running Number Students of SDI Minasa Upa Makassar City. This study is a quantitative study aimed at determining the level of Physical Education Learning Outcomes 40 M Students of SDI Minasa Upa Makassar City. The population in this study were all 414 students of SDI Minasa Upa while the research sample consisted of 30 people. Data collection techniques using questionnaires and observation sheets. The data analysis technique used is descriptive statistics using computer facilities through the SPSS version 20.00 program. Based on the results of the data and discussion of this study, it can be concluded that the level of Physical Education Learning Outcomes 40 M Students of SDI Minasa Upa Makassar City is in the very high category.
\end{abstract}

Keywords: Learning Outcomes; Run 40 m, Physical Education

Accepted: $23^{\text {th }}$ of January 2022

Correspondence author: Nur Indah Atifah Anwar, Universitas Negeri Makassar, Indonesia. E-Mail: nurindah@unm.ac.id

DOI http://dx.doi.org/10.31851/hon.v5i1.7086 dd

\section{(c) (i) (2)}

Jurnal Halaman Olahraga Nusantara licensed under a Creative Commons Attribution-ShareAlike 4.0 International License

\section{INTRODUCTION}

Physical education as one of the fields of education that is integrated with education as a whole, then development in our homeland is emphasized on the development of human resources as a whole, namely humans who are physically, mentally, mentally healthy and have intelligence and skills. Therefore, physical education needs to be improved. One aspect of achieving full Indonesian human development is the aspect of physical education and sports (Okilanda et al., 2018).

Physical education has a very important role in intensifying the implementation of education as a process of human development that lasts a lifetime. Physical education provides opportunities for students to be directly involved in various learning experiences through physical activities, playing, and exercising that are carried out in a systematic, directed and planned manner. The 


\section{OLATRAGA

provision of learning experiences is directed at fostering, as well as forming a healthy and active lifestyle (Taufik et al., 2021). Through physical education, it is expected that students can gain various experiences to express personal impressions that are fun, creative, innovative, skilled, improve and maintain physical fitness and understanding of human movement (Maretno \& Arisman, 2020)

In athletics, especially the short distance running, it is a relatively simple number compared to other numbers, namely: middle, long distance running to the most distant number, namely marathon running. Athletics is a means for physical education in an effort to increase endurance, strength, speed, agility and so on. Actually, athletic activities have been reflected in early human life, namely walking, running, jumping and throwing and even fighting with animals. Early humans at that time carried out walking, running, jumping, throwing and struggling movements in an effort to defend their lives from disturbances from animals or wild creatures that lived in ancient times (Putra et al., 2020)

The term "athletics" comes from the Greek word Athlon which means competition, competition and struggle. While the person who does it is called Athlete (athlete). Broadly speaking, the branches that are competed/contested in athletics can be divided into four parts, namely 1) walking numbers, 2) running numbers, 3) jumping numbers, 4) throwing numbers.

In athletics, especially the short distance running, it is a relatively simple number compared to other numbers, namely: middle, long distance running to the most distant number, namely marathon running.

Elementary school students generally like sports learning, but what happens in the field shows that students are less mobile, students are less focused and enthusiastic in carrying out learning, lack enthusiasm, and are lazy, especially the 40 meter running material (Putri et al., 2021)

The problems that exist in these students are obstacles in the learning process that greatly affect student learning outcomes, students who do not understand and understand basic running techniques so that many students still 
ask when taking grades and most students just run not knowing basic techniques such as start techniques, techniques when running, and techniques to enter the finish line so that it can be stated that learning outcomes are still low.

Researchers are interested in researching at SD Minasa Upa because in terms of achievement many students have achieved but there are still many students who do not understand or even understand the basic techniques of running short distances, especially the 40 meter run, in the learning process. Learning outcomes are the level of success in the form of numbers or values that students have after participating in the learning process (Arisman et al., 2021). In general, students who are research subjects are students who are very ranged about learning outcomes, considering that learning outcomes are the main ones that will become a reference for entering the junior high school level. And according to the results of interviews from PJOK teachers said that there are still many students who are indifferent in assessment, considering the current condition of the pandemic. Therefore, the need for encouragement from both teachers and parents (Nopianto et al., 2020).

There are several solutions to improve the 40 meter running number learning, namely by using variations of learning so that students do not get bored, the use of supporting facilities and infrastructure, and the use of learning methods and media in order to improve learning outcomes (Arisman \& Agun Guntara, 2021).

Based on the above background, the researcher is interested in researching with the title: "Analysis of Physical Education Learning Outcomes 40 M Running Number of Students of SDI Minasa Upa Makassar City".

\section{METHOD}

This research is descriptive quantitative research is research that describes the existing situation according to reality. Research is usually carried out to draw generalizations from observations that are not in-depth, but generalizations made can be more accurate if a "representative" sample is used. The learning outcomes 


\section{OLATRAGA

obtained are then analyzed by descriptive analysis as outlined in the form of percentages.

This research was carried out at SDI Minasa Upa Makassar This research was carried out from July 2021 to August 2021. The sample in this study were 26 students of SDI Minasa Upa Makassar. This sampling uses propusive sampling or certain considerations, namely direct appointments.

The research instrument is the tool used in taking the data, namely the observation sheet. This observation sheet aims to make it easy to record data. Data on the results of learning to run 40 meters were taken from PJOK teachers which included affective, cognitive and psychomotor. By documenting the results of the teacher's assessment by taking photos of student learning outcomes.

Data collection is intended to obtain relevant, accurate, and reliable data, the methods used in this study are:

\section{Observation method}

The technique of observation or observation is an activity of recording phenomena that is carried out systematically, namely the 40 meter short distance running data. Collecting data using an observation sheet to retrieve learning outcomes data given by the PJOK SDI Minasa Upa teacher.

\section{Documentation or Literature Study}

According to (Sugiono, 2016), "documentation is seeking and collecting data on matters in the form of notes, transcripts, books, newspapers, magazines, minutes, and so on". Data collection techniques by studying and exploring literature books, and other written information related to the research topic. In this study, taking documentation of learning outcomes and teacher documentation during the research.

Data Before testing the hypothesis, it is necessary to test prerequisites. Testing of measurement data related to research results aims to help the analysis to be better. For that in this study will be tested for normality. So the overall analysis of statistical data used generally uses statistical analysis with the help of the SPSS version 21.0 computer program with a significant level of $95 \%$ or $=0.05$ 
Table 1. Success Indicator

\begin{tabular}{ccc}
\hline No & Value Range & Information \\
\hline 1 & $80-100$ & Very well \\
2 & $66-79$ & Good \\
3 & $56-65$ & Enough \\
4 & $40-55$ & Not enough \\
5 & $0-39$ & Less once \\
\hline
\end{tabular}

Source: Assessment of elementary school learning outcomes by the Ministry of National Education

After the data is obtained, to draw conclusions, the formula used is as follows:

$$
\mathrm{P}=\mathrm{F} / \mathrm{N} X 100 \%
$$

Description :

$\mathrm{P}=$ Percentage sought (Relative Frequency)

$\mathrm{F}=$ Frequency of use

$\mathrm{N}=$ Number of respondents

In this chapter, the presentation of the results of data analysis and discussion will be presented. Presentation of the results of descriptive statistical analysis and hypothesis testing. Then a discussion of the results of the analysis and its relation to the theory that underlies this research is carried out to provide interpretation and the results of data analysis

\section{RESULT AND DISCUSSION}

The results of learning to run $40 \mathrm{~m}$ Students of SDI Minasa Upa Makassar City data on the results of learning to run $40 \mathrm{~m}$ were taken by the PJOK teacher through observation sheets. The results of the research from 30 samples in this case will later be included in the assessment table. The overall data obtained from the respondents are as follows.

Table 2. Score Data Obtained from the Sample

\begin{tabular}{ll}
\hline Variable & Learning Outcomes \\
\hline $\mathrm{N}$ & 30 \\
Average & 81.477 \\
Maksimun & 93.0 \\
Minimun & 75.0 \\
Median & 81.150 \\
Mode & 83 \\
Standard deviation & 4.6599 \\
\hline
\end{tabular}


Based on table 4.1 above, it can be described as follows: The results of the

$40 \mathrm{~m}$ running at SDI Minasa Upa obtained an average value (mean) of 81,477, a median of 81,150 , a mode of 83 , a minimum data of 75.0 , a maximum data of 93.0, and a standard deviation of 4.6599.

The frequency distribution of each variable is as follows: The level of learning outcomes of $40 \mathrm{~m}$ running at SDI Minasa Upa students, Makassar City

The frequency distribution of the $40 \mathrm{~m}$ running learning outcomes for students at SDI Minasa Upa Makassar City is as follows:.

Table 3. Distribution of $40 \mathrm{~m}$ running learning outcomes for students at SDI Minasa Upa Makassar City

\begin{tabular}{cclcc}
\hline No & Value Range & Category & Frequency & Percentage (\%) \\
\hline 1 & $80-100$ & Very well & 18 & $60 \%$ \\
2 & $66-79$ & Good & 12 & $40 \%$ \\
3 & $56-65$ & Enough & 0 & $0 \%$ \\
4 & $40-55$ & Not enough & 0 & $0 \%$ \\
5 & $0-39$ & Less once & 0 & $0 \%$
\end{tabular}

Amount

30

$100 \%$

From the table and figure above, it is known that the level of learning outcomes for running is $40 \mathrm{~m}$, in the very high category with a percentage of $60 \%$, in the high category with $40 \%$, in the moderate category with a percentage of $0 \%$, in the low category with a percentage of $0 \%$, and in the very category. low $0 \%$. This shows that student learning outcomes are in the very high category.

1) Learning outcomes affective indicators of learning outcomes to run $40 \mathrm{~m}$ In the results of this data description will discuss the average, standard deviation, median, the highest and lowest values of cognitive indicator learning outcomes. That the learning outcomes of passing affective indicators. That the mean value is 83.67 with a median of 80.00 standard deviations of 5.713 , a minimum of 75 and a maximum of 90 .

Table 4. Distribution of data on the frequency of learning outcomes to run $40 \mathrm{~m}$ affective indicators.

\begin{tabular}{ccccc}
\hline No & Value Range & Category & Frequency & Percentage (\%) \\
\hline 1 & $80-100$ & Very well & 14 & $40 \%$ \\
2 & $66-79$ & Good & 16 & $60 \%$ \\
\hline
\end{tabular}




\section{OLAHRAGA}

JURAAL JUIIKCOL NURANTARA
Jendral A. Yani Street Lorong Gotong Royong 9/10 Ulu Palembang South Sumatera

email jurnal: jurnalhon@univpgri-palembang.ac.id situs web: http://www.univpgri-palembang.ac.id

\section{Accredited}

SINTA 3

$\begin{array}{lccll}3 & 56-65 & \text { Enough } & 0 & 0 \% \\ 4 & 40-55 & \text { Not enough } & 0 & 0 \% \\ 5 & 0-39 & \text { Less once } & 0 & 0 \%\end{array}$

Amount

$100 \%$

Based on the table above, it can be seen that the criteria for the learning outcomes of affective indicators are there. 0 students or $0 \%$ for the very poor category, 0 students or $0 \%$ for the poor category, 0 students or $0 \%$ in the sufficient category, then for the good category there are 16 or $60 \%$ students, very good category 14 or $40 \%$ students. So it can be concluded that the results of learning to run $40 \mathrm{~m}$ students of SDI Minasa Upa Makassar City are affective indicators in the good category with a percentage of $60 \%$.

2) Cognitive indicator learning outcomes

In the results of this data description, we will discuss the average, standard deviation, median, the highest and lowest values of learning outcomes to run $40 \mathrm{~m}$ cognitive indicators.

The value of learning outcomes for running $40 \mathrm{~m}$ is a cognitive indicator of students at SDI Minasa Upa Makassar City. That the mean value is 81.33 with a median of 79.00 standard deviation 6.630 , a minimum of 75 and a maximum of 94.

Table 5. Distribution of data on the frequency of learning outcomes to run $40 \mathrm{~m}$ cognitive indicators.

\begin{tabular}{ccccc}
\hline No & Value Range & Category & Frequency & Percentage (\%) \\
\hline 1 & $80-100$ & Very well & 14 & $40 \%$ \\
2 & $66-79$ & Good & 16 & $60 \%$ \\
3 & $56-65$ & Enough & 0 & $0 \%$ \\
4 & $40-55$ & Not enough & 0 & $0 \%$ \\
5 & $0-39$ & Less once & 0 & $0 \%$
\end{tabular}

Amount $100 \%$

Based on the table above, it can be seen that the criteria for learning outcomes for physical education are cognitive indicators. 0 students or $0 \%$ for the very poor category, 0 students or $0 \%$ for the poor category, 0 students or $0 \%$ in the sufficient category, then for the good category there are 16 students or $60 \%$ 


\section{OLA $\overline{\text { HRAGA }}$

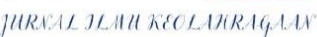 \\ Jendral A. Yani Street Lorong Gotong Royong 9/10 Ulu \\ Palembang South Sumatera \\ Accredited \\ email jurnal: jurnalhon@univpgri-palembang.ac.id situs web: http://www.univpgri-palembang.ac.id

students, very good category 14 students or $40 \%$ students. So it can be concluded that the results of learning to run $40 \mathrm{~m}$, the cognitive indicators of the students of SDI Minasa Upa Makassar City are in the good category with a percentage of $60 \%$.

3) Psychomotor indicator learning outcomes

In the results of this data description, we will discuss the average, standard deviation, median, highest and lowest values of psychomotor indicator learning outcomes.

The value of passing learning outcomes in SDI Minasa Upa students. That the mean value is 78.43 with a median of 75.00 standard deviations of 5.703 , a minimum of 75 and a maximum of 95 .

Table 6. Distribution of data on the frequency of learning outcomes to run $40 \mathrm{~m}$ psychomotor indicators

\begin{tabular}{ccccc}
\hline No & Value Range & Category & Frequency & Percentage (\%) \\
\hline 1 & $80-100$ & Very well & 9 & $30 \%$ \\
2 & $66-79$ & Good & 21 & $90 \%$ \\
3 & $56-65$ & Enough & 0 & $0 \%$ \\
4 & $40-55$ & Not enough & 0 & $0 \%$ \\
5 & $0-39$ & Less once & 0 & $0 \%$
\end{tabular}

Amount 30

Based on the table above, it can be seen that the criteria for learning to run $40 \mathrm{~m}$ are psychomotor indicators. 0 students or $0 \%$ for the very poor category, 0 students or $0 \%$ for the poor category, 0 students or $0 \%$ in the sufficient category, then for the good category there are 21 or $70 \%$ students, the very good category 9 or $30 \%$ students. So it can be concluded that the results of learning to run $40 \mathrm{~m}$ psychomotor indicators for students at SDI Minasa Upa Makassar City are in the good category with a percentage of $70 \%$.

Table 7. Frequency distribution of $40 \mathrm{~m}$ running learning outcomes for students at SDI Minasa Upa Makassar City based on KKM

\begin{tabular}{ccc}
\hline KKM 75 & Frequency & Percentage (\%) \\
\hline Complete & 30 & $100 \%$ \\
Not finished & 0 & $0 \%$ \\
Amount & 30 & $100 \%$ \\
\hline
\end{tabular}




\section{Accredited}

SINTA 3

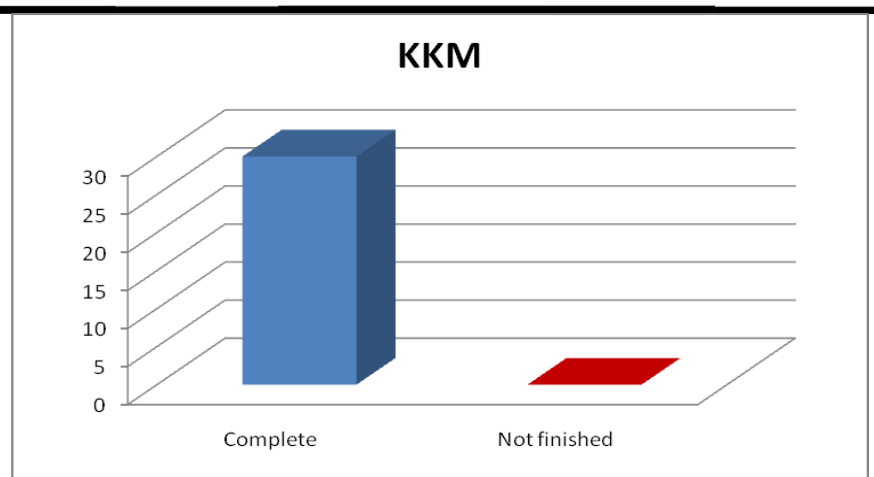

Figure 1. bar chart of the results of learning to run $40 \mathrm{~m}$ according to KKM

Based on the table above, it can be seen that the criteria for the results of learning to run $40 \mathrm{~m}$ according to completeness exist. 30 students or $100 \%$ who completed while those who did not complete, 0 students or $0 \%$. So it can be concluded that the results of learning to run $40 \mathrm{~m}$ for students at SDI Minasa Upa Makassar City are all complete.

\section{The level of learning outcomes of $\mathbf{4 0}$ m running students at SDI Minasa Upa Makassar City}

The level of learning outcomes for running is $40 \mathrm{~m}$, in the very high category with a percentage of $60 \%$, in the high category with a percentage of $40 \%$, in the moderate category with a percentage of $0 \%$, in the low category with a percentage of $0 \%$, and in the very low category $0 \%$. This shows that student learning outcomes are in the very high category.

The level of learning outcomes is very high where students have good mastery of the material, have a good attitude and respect teachers, parents, friends and the surrounding environment, and the ability to practice is also good even during a pandemic the assessment via whatsapp and video proves that students have good cognitive, affective, and psychomotor abilities according to the learning outcomes of 30 students all completed (Okilanda et al., 2021)

\section{CONCLUSION}

Based on the results of the research described in Chapter IV, the following conclusions and suggestions can be put forward:

the level of student learning outcomes in the very high category. 


\section{OLATRAGA

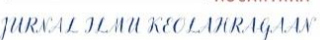 \\ Jendral A. Yani Street Lorong Gotong Royong 9/10 Ulu \\ Palembang South Sumatera \\ Accredited \\ email jurnal: jurnalhon@univpgri-palembang.ac.id situs web: http://www.univpgri-palembang.ac.id

\section{SUGGESTION}

Based on the research conclusions that have been described, the following suggestions can be confirmed.

1. Teachers are expected to be able to strengthen their motivation in order to improve students' 40 meter running learning outcomes.

2. Students are expected to optimize physical education learning, so that they can improve students' 40 meter running learning outcomes.

3. Parents of students are expected to be able to strengthen their motivation in order to improve their children's 40 meter running learning outcomes.

4. This research discusses the motivation for physical education learning outcomes. For this reason, it is recommended for further researchers to discuss, expand or add research variables for the development of research in the field of physical education.

\section{REFERENCES}

Arisman, A., \& Agun Guntara, R. (2021). The Research Of Students' Motor Ability In Archery Extracurricular. Jurnal Maenpo: Jurnal Pendidikan Jasmani Kesehatan Dan Rekreasi, 11(1), 13. https://doi.org/10.35194/jm.v11i1.1216

Arisman, A., Okilanda, A., Dwiansyah Putra, D., \& El Cintami Lanos, M. (2021). Resistensi Yoga dalam Meningkatkan Konsentrasi Ketepatan Memanah. Jurnal Patriot, 3, 71-81. https://doi.org/10.24036/patriot.v

Iskandar. Adam. Hamka.2019.Athletic Textbook. Makassar: Makassar State University.

Kurniwan Deni. 2015. Integrated Thematic Learning (Theory, Practice and Assessment). Bandung: Alphabeta. Mold I.

Maretno, M., \& Arisman, A. (2020). Ladder Drill dalam Meningkatkan Kelincahan Atlet Bola Voli. Jurnal Muara Olahraga, 3(1), 1-20.

Nopianto, W., El Cintami Lanos, M., \& Arisman, A. (2020). The Effect of Mixed Inpact Aerobic Gymnam on The Improvement of Physical Fitness for High School. JIPES, 6(2), 55-61.

Okilanda, A., Arisman, A., Lestari, H., Lanos, M. E. C., Fajar, M., Putri, S. A. R., \& Sugarwanto, S. (2018). Sosialisasi Petanque Sebagai Olahraga Masa Kini. Jurnal Bagimu Negeri, 2(1), 69-76. https://doi.org/10.26638/jbn.638.8651

Okilanda, A., Dlis, F., Humaid, H., Putra, D. D., Arisman, A., \& Muslimin, M. 
Jendral A. Yani Street Lorong Gotong Royong 9/10 Ulu Palembang South Sumatera

email jurnal: jurnalhon@univpgri-palembang.ac.id situs web: http://www.univpgri-palembang.ac.id

\section{Accredited}

SINTA 3

(2021). Defense Warm-Up Exercise Material for 13-Age Athlete Using Video Technology in Covid-19 Era. International Journal of Human Movement and Sports Sciences, 9(4), 629-634. https://doi.org/10.13189/saj.2021.090404

Putra, D. D., Okilanda, A., Arisman, A., Lanos, M. E. C., Putri, S. A. R., Fajar, M., Lestari, H., \& Wanto, S. (2020). Kupas Tuntas Penelitian Pengembangan Model Borg \& Gall. Wahana Dedikasi: Jurnal PkM Ilmu Kependidikan, 3(1), 46. https://doi.org/10.31851/dedikasi.v3i1.5340

Purwanto.2015. Evaluation of Learning Outcomes. Yogyakarta: Learning library.

Putri, R. A. S., Lanos, C. E. M., Lestari, H., \& Fajar, M. (2021). Student perception of the basic engineering learning model throught the play approach. Jurnal Halaman Olahraga NUsantara, 4(1), 114-124. https://doi.org/http://dx.doi.org/10.31851/hon.v4i1.5120

Sugiyono. 2016. Quantitative and qualitative research methods and R\&D. Bandung: Alphabeta. 20th edition.

Suyono. Harianto. 2014. Learning and Learning. Bandung: PT. Remaja Rosda Karya

Slameto, 2016. Learning and Influencing Factors. Jakarta: Rineka Cipta

Taufik, M. S., Solahuddin, S., Arisman, A., Ridlo, A. F., \& Iskandar, T. (2021). Improve Learning Outcomes of Basketball Lay Up Shoot in Junior High School. COMPETITOR: Jurnal Pendidikan Kepelatihan Olahraga, 13(2), 154. https://doi.org/10.26858/cjpko.v13i2.19412 